\title{
NILAI GUNA (KEPUASAN) GREEN TECHNOLOGY E-TOLL SEBAGAI SALAH SATU ALTERNATIF LAYANAN PADA KONSUMEN PENGGUNA TOL DALAM KOTA JAKARTA
}

\author{
Enggal Sriwardiningsih \\ Management Department, School of Business Management, Universitas Bina Nusantara \\ Jln. K.H. Syahdan No. 9, Palmerah, Jakarta Barat 11480 \\ enggalnabeel@yahoo.com
}

\begin{abstract}
Consumer satisfaction should be provided by organization. The Government service in the form of etoll green technology is an alternative service in toll road for public. This service is still new in the implementation. Therefore, it is necessary to do a study in the level of elasticity of the e-toll service. Consumer satisfaction from toll users becomes a measure of the success rate from this service. Consumer satisfaction from toll users who use e-toll will be achieved if they are satisfied with the e-toll product and GTO service. This study aims to test a model that explains consumer satisfaction from e-toll users. The theory underlying this study was service quality and satisfaction. The study was conducted on the toll roads in Jakarta. Unit analysis was e-toll users. Samples were taken based on convenient sampling. Structural Equation Modelling used SPSS 16.0 software and elasticity formula was used to test the hypothesis; while the implication for transport domain.
\end{abstract}

Keywords: consumer satisfaction, green technology, e-toll service

\begin{abstract}
ABSTRAK
Nilai guna atau rasa puas konsumen harus diberikan oleh layanan suatu organisasi. Layanan pemerintah dalam bentuk green teknology e-toll adalah satu alternatif layanan di jalan tol kepada masyarakat yang masih baru penerapannya. Oleh karena itu perlu adanya kajian tingkat elastisitas layanan e-toll tersebut. Kepuasan konsumen pengguna tol ini menjadi tolok ukur tingkat kesuksesan alternatif layanan ini. Kepuasan konsumen pengguna jalan tol yang menggunakan e-toll akan tercapai jika pengguna merasa puas dengan produk e-toll dan layanan GTO. Penelitian ini bertujuan untuk menguji model yang menjelaskan kepuasan konsumen pengguna e-toll. Teori yang melandasi penelitian ini adalah kualitas layanan dan kepuasan. Penelitian dilakukan di jalan tol dalam kota Jakarta. Unit analisis adalah pengguna e-toll. Sampel diambil berdasarkan convenient sampling. Structural Equation Modelling menggunakan software SPSS 16.0 dan formula elastisitas digunakan untuk menguji hipotesis; sementara implikasi untuk domain transportasi.
\end{abstract}

Kata kunci: nilai guna (kepuasan), green technology, layanan e-toll 


\section{PENDAHULUAN}

Nilai guna yang dirasakan konsumen akan terjadi manakala kepuasan konsumen tersebut tercapai (Arief, 2007). Adanya upaya pemerintah dalam menggalakkan green technology e-toll sebagai salah satu alternatif layanan kepada masyarakat masih baru penerapannya. Oleh karena itu perlu adanya kajian tingkat elastisitas layanan $e$-toll tersebut (Arendt \& Brettel, 2010).

Teknologi hijau (green technology) alam sekitar adalah penggunaan teknologi untuk memelihara alam sekitar dari dampak aktivitas negatif yang merugikan manusia. Saat ini teknologi hijau diharapkan akan menjadi penyelesaian berbagai aspek sosial, ekonomi, dan alam sekitar. Oleh karena itu, teknologi hijau (green technology) merujuk pada aplikasi produk, peralatan serta sistem untuk memelihara alam sekitar. Ruang lingkup dari green technology ini adalah teknologi sumber alam hijau, bangunan hijau, nanoteknologi hijau, dan alamtologi. Konsep penerapan teknologi hijau diterapkan dalam kehidupan manusia untuk keberlangsungan. Keberlangsungan adalah upaya untuk memenuhi kebutuhan masyarakat secara terus menerus di masa depan tanpa merusak atau menghabiskan sumber daya alam. Penghematan sumber daya alam salah satunya dengan inovasi (Vachon \& Klassen, 2006). Inovasi adalah upaya untuk mengembangkan alternatif teknologi yang ramah lingkungan guna memenuhi kebutuhan manusia tanpa merusak lingkungan.

Salah satu produk teknologi inovasi pembayaran baru yang dikenal saat ini adalah e-toll sebagai alat transaksi pengganti tiket kertas yang biasanya didapatkan pengguna jalan tol. Penggunaan e-toll merupakan suatu inovasi dari teknologi sistem pembayaran yang menghemat sumber daya alam kayu, mengurangi sampah kertas yang hanya sekali pakai selama ini, dan mengurangi kemacetan. Suatu survei mengenai e-toll card telah diluncurkan terhadap 100 orang responden. Survei ini mengenai pandangan mereka terhadap e-toll card sebagai solusi teknologi hijau yang berdampak positif pada lingkungan atau pencitraan pejabat semata. Terlepas dari besaran responden yang berpendapat pada pencitraan dari pejabat yang terkait, perlu digarisbawahi adanya dukungan positif yang cukup besar dari masyarakat yang perlu direspons baik oleh penyedia layanan e-toll card. Masalah terjadi dalam pelaksanaannya, antara lain sebagai berikut. Pertama, e-toll pass belum dapat berfungsi seperti yang diharapkan. E-toll yang diharapkan dapat mengurangi kemacetan malah terkadang menimbulkan kemacetan. Kedua, petugas teknologi informasi (IT) yang mengawasi alat $e$ toll pass kurang sigap dalam mengelola permasalahan sistem alat tersebut. Ketiga, lemahnya edukasi pemasaran e-toll card karena rendahnya pemahaman masyarakat mengenai e-toll card guna mendukung terciptanya daya dukung lingkungan yang berkelanjutan.

Sepanjang pengetahuan, masih sangat jarang yang memberikan perhatian khusus pada penelitian persepsi kepuasan yang didapatkan pengguna e-toll card sehingga kesuksesan program pemerintah ini sulit untuk diprediksi keberlangsungannya. Oleh karena itu, penelitian tentang nilai guna (kepuasan) green technology e-toll sebagai salah satu alternatif layanan pada konsumen pengguna tol dalam kota Jakarta dilakukan. Penelitian ini menekankan kepuasan konsumen sebagai utilitas yang didapatkan konsumen dari penggunaan $e$-toll card. Harapannya, makin besar utilitas atau kepuasan yang didapatkan, konsumen akan melakukan makin banyak transaksi dengan e-toll card; memberikan rekomendasi positif pada calon pemgguna lainnya; dan lebih nyaman bertransaksi dengan e-toll card daripada dengan sistem konvensional kertas nongreen. Hal tersebut menjadi acuan untuk menjawab beberapa beberapa pertanyaan penelitian berikut ini: seberapa besar kepuasan konsumen dari menggunakan e-toll card ini selama ini; dan jumlah kartu yang akan dibeli oleh konsumen jika penyedia e-toll card meningkatkan kualitas produk e-toll card dan layanan Gerbang Tol Otomatis (GTO).

Berdasarkan hal yang sebagaimana telah diuraikan, terdapat persoalan yang menarik untuk dikaji, yaitu: (1) bagaimanakah pengaruh antara kualitas produk kartu e-toll dan layanan GTO 
terhadap kepuasan konsumen; (2) bagaimanakah pengaruh antara kualitas produk kartu e-toll terhadap kepuasan konsumen; (3) seberapa besar kepekaan atau reaksi konsumen terhadap perubahan variabel kualitas produk kartu e-toll terhadap jumlah kartu e-toll yang akan diminati oleh konsumen; (4) bagaimanakah pengaruh layanan GTO terhadap kepuasan konsumen; (5) seberapa besar kepekaan atau reaksi konsumen terhadap perubahan kualitas layanan GTO terhadap jumlah kartu e-toll yang akan diminati oleh konsumen.

\section{Tinjauan Literatur}

Salah satu pendekatan teori perilaku konsumen adalah pendekatan nilai guna ordinal. Pendekatan nilai guna ordinal yaitu manfaat atau kenikmatan masyarakat dari mengonsumsi barangbarang tidak dikuantifikasi namun dirasakan. Tingkah laku konsumen untuk memilih barang-barang yang akan memaksimumkan kepuasannya ditunjukkan dengan bantuan kurva kepuasan sama (indifference curve), yaitu kurva yang menggambarkan gabungan barang yang akan memberikan nilai guna (kepuasan) yang sama (Arief, 2007). Asumsi utama teori nilai guna adalah benda dan jasa yang dikonsumsi untuk memperoleh manfaat atau kegunaan.

Konsep konsumen bersifat abstrak. Pencapaian kepuasan dapat merupakan proses yang sederhana maupun kompleks dan rumit. Peranan setiap individu dalam pemberian service sangat penting dan berpengaruh terhadap kepuasan yang dibentuk. Adapun faktor-faktor yang memengaruhi persepsi dan harapan konsumen, antara lain (Kotler \& Armstrong, 2006; Novikova, 2009): kebutuhan dan keinginan yang berkaitan dengan hal-hal yang dirasakan konsumen ketika sedang mencoba melakukan transaksi dengan produsen produk; pengalaman masa lalu ketika mengonsumsi produk dari perusahaan maupun pesaing-pesaingnya; dan pengalaman dari teman-teman.

Pengertian kepuasan atau ketidakpuasan konsumen dilihat dari kesesuaian antara harapan (expectation) konsumen dengan persepsi dan pelayanan yang diterima (kenyataan yang dialami). Umumnya harapan konsumen merupakan perkiraan atau keyakinan konsumen tentang hal yang akan diterimanya jika ia membeli atau mengonsumsi suatu produk (barang atau jasa). Sementara itu, kinerja yang dirasakan adalah persepsi konsumen terhadap hal yang dia terima setelah mengonsumsi produk yang dibeli. Kepuasan merupakan fungsi dari kesan kinerja (performance) dan harapan (expectation). Jika kinerja berada di bawah harapan, konsumen tidak puas (dissatisfaction); jika kinerja melebihi harapan, pelanggan sangat puas atau senang (delight). Banyak perusahaan berfokus pada tingkat kepuasan konsumen karena konsumen mudah mengubah pikiran jika mendapatkan hal yang lebih baik. Konsumen yang tidak puas akan selalu mengganti produk mereka dengan produk pesaing. Mereka yang sangat puas sukar mengubah pilihannya. Setelah mengonsumsi barang atau jasa untuk pertama kalinya, konsumen menilai tindakan dan pengalaman yang diprolehnya. Selanjutnya, konsumen menilai tindakan dan pengalaman yang diprolehnya untuk menentukan tingkat kepuasannya.

Konsumen yang sangat puas akan tetap setia dalam waktu yang lebih lama, membeli lebih banyak ketika perusahaan memperkenalkan produk baru dan memperbarui produk-produk yang ada, membicarakan hal-hal yang baik tentang perusahaan dan produknya, memberi perhatian yang lebih sedikit pada merek dan iklan para pesaing serta kurang peka terhadap harga, menawarkan gagasan tentang jasa atau produk kepada perusahaan, dan membutuhkan biaya pelayanan yang lebih kecil dibandingkan biaya pelayanan pelanggan baru karena transaksinya rutin.

Sementara, elastisitas adalah perbandingan perubahan proporsional dari sebuah variabel dengan perubahan variabel lainnya (Arief, 2007). Dengan kata lain, elastisitas mengukur seberapa besar kepekaan atau reaksi konsumen terhadap perubahan suatu variabel penyebab. Penggunaan paling umum dari konsep elastisitas adalah untuk meramalkan hal yang akan terjadi jika harga barang/jasa dinaikkan. Dalam hal ini harga tidak dibicarakan, tetapi kualitas produk dan layanan yang 
diterima oleh konsumen e-toll. Pengetahuan mengenai seberapa dampak perubahan kualitas produk dan kualitas layanan terhadap kepuasan sangatlah penting. Bagi produsen, pengetahuan ini digunakan sebagai pedoman seberapa besar ia harus mengubah kualitas produk dan layanannya. Hal ini sangat berkaitan dengan seberapa besar penerimaan penjualan yang akan ia peroleh. Sebagai contoh, anggaplah kualitas produk dan layanan meningkat sehingga seorang produsen akan mendapatkan jumlah permintaan meningkat. Menurut hukum permintaan, tindakan menaikkan kualitas produk dan layanan e-toll ini dengan asumsi harga tetap akan menggeserkan kurva permintaan ke kanan sesuai dengan kepuasan konsumen yang bergeser ke kanan. Jelas di sini bahwa produsen harus mempertimbangkan tingkat elastisitas barang produksinya sebelum membuat suatu keputusan. Ia harus memperkirakan seberapa besar kepekaan konsumen atau seberapa besar konsumen akan bereaksi jika ia mengubah kualitas produk dan layanan dalam sebesar sepuluh persen, dua puluh persen, dan seterusnya.

\section{Green Technology}

Ruang lingkup dari green technology adalah teknologi sumber alam hijau, bangunan hijau, nanoteknologi hijau, dan alamtologi. Konsep penerapan teknologi hijau diterapkan dalam kehidupan manusia untuk keberlangsungan. Keberlangsungan adalah upaya untuk memenuhi kebutuhan masyarakat secara terus menerus pada masa depan tanpa merusak atau menghabiskan sumber daya alam. Penghematan sumber daya alam salah satunya dengan inovasi. Inovasi adalah upaya untuk mengembangkan alternatif teknologi yang ramah lingkungan guna memenuhi kebutuhan manusia tanpa merusak lingkungan (Vachon \& Klassen, 2006)

Salah satu produk teknologi inovasi pembayaran baru yang dikenal saat ini adalah e-toll sebagai alat transaksi pengganti tiket kertas yang biasanya didapatkan pengguna jalan tol. Penggunaan e-toll merupakan suatu inovasi dari teknologi sistem pembayaran yang menghemat sumber daya alam kayu, mengurangi sampah kertas yang hanya sekali pakai selama ini dan mengurangi kemacetan. Teknologi hjau (green technology) merujuk kepada pembangunan dan aplikasi produk, peralatan serta sistem untuk memelihara alam sekitar, dan meminimalkan peran negatif aktivititas manusia.

Ruang lingkup teknologi hijau adalah sebagai berikut. Tenaga sumber alam; merupakan isu penting dalam teknologi hijau dan ini termasuk pembangunan bahan bakar alternatif atau sumber tenaga yang boleh diperbarui. Bangunan hijau; bidang ini merangkum semua tahap pembangunan, dari pemilihan bahan bangunan hingga pemilihan lokasi bangunan. Nanoteknologi hijau; bidang ini melibatkan manipulasi bahan pada skala nanometer atau satu per milyar meter. Nanoteknologi hijau adalah aplikasi teknologi hijau dalam bidang nanoteknologi. Alamtologi; suatu teknologi yang jelas mengikut fitrah alam dan hanya mengembangkannya sesuai dengan susunan yang lebih teratur.

\section{E-toll Card}

Jika diamati dari ruang lingkup teknologi hijau, e-toll dalam hal ini masuk dalam bangunan hijau karena mengikuti tahap pembangunan hijau dari pemilihan bahan kertas menjadi kartu daur ulang. E-toll card adalah kartu prabayar contactless smartcard yang diterbitkan oleh Bank Mandiri bekerja sama dengan operator tol. Saat ini operator tol yang telah bekerja sama yaitu Jasa Marga, Cipta Marga Nusaphala Persada, Marga Mandala Sakti, dan Jalan tol Lingkar Luar Jakarta (JLJ). Etoll card digunakan untuk transaksi pemabayaran tol dan selanjutnya dapat digunakan untuk transaksi di luar merchant toll. Manfaat e-toll card bagi pemegang kartu adalah sebagai pengganti uang tunai, transaksi pembayaran tol lebih cepat dibandingkan dengan menggunakan cash, dan dapat digunakan untuk transaksi di luar merchant tol (Indomaret, SPBU, beberapa mechant F\&B, dsb). Meskipun begitu, e-toll card memiliki kelemahan secara ekonomis, yaitu jika dalam jangka waktu 12 bulan (1 tahun) kartu tidak digunakan untuk transaksi isi ulang ataupun pembayaran/purchase, pemegang kartu akan dikenakan biaya administrasi Rp10 ribu (dapat berubah sesuai ketentuan yang berlaku) pada saat pengaktifan kembali. (Bank Mandiri, n.d.) 
Dengan layanan e-toll, pengguna jalan tol cukup melintasi gerbang tol otomatis bertanda $e$ toll. Setelah terdengar bunyi bip-bip di perangkat on board unit (OBU) yang terpasang di kaca depan palang pintu, gardu tol pun akan terbuka dan transaksi selesai. Saat ini layanan E-toll dapat digunakan di 17 Gerbang Tol Otomatis (GTO) seperti di ruas tol Cililitan, Halim, Cengkareng, Kapuk, Pondok Ranji, Cikunir 2, Dukuh 1-3, Pasar Rebo, serta Bekasi Barat 1 dan 2. (GoldBank, 2012)

Jika pemegang kartu melakukan komplain di gerbang tol, petugas tol melakukan pencetakan histori transaksi, dengan melihat data tanggal dan jam transaksi. Jika terdapat pendebetan dalam waktu tidak lama, petugas dapat melakukan penggantian untuk kelebihan pendebetan tersebut berdasarkan petty cash yang tersedia. (Bank Mandiri, n.d.)

\section{METODE}

Jenis penelitian yang dilakukan adalah penelitian asosiatif untuk mengetahui pengaruh kualitas produk dan kualitas layanan terhadap kepuasan konsumen dengan kuesioner sebagai data primer (Sekaran, 2003). Data primer melalui kuesioner dalam penelitian ini menggunakan skala pengukuran Likert, yaitu skala yang menyatakan setuju atau tidak setuju terhadap pertanyaan yang diajukan dengan skala 1 sampai dengan 5 . Unit analisis yang dituju adalah pengguna e-toll. Time horizon yang digunakan adalah cross-sectional. Teknik sampling yang digunakan merupakan teknik pengambilan sampel dengan nonprobability sampling sebanyak 100 responden. Metode analisis yang digunakan untuk pengolahan data adalah dengan software SPSS 16.0 untuk menguji regresi berganda.

Kerangka berpikir dalam penelitian ini adalah ingin melihat pengaruh dari kualitas produk $e$ toll dan layanan GTO terhadap kepuasan konsumen pengguna e-toll card tersebut. Lebih lanjut peneliti ingin melihat dampak elastisitas dari perubahan kualitas produk dan layanan terhadap kepuasan pengguna. Hal ini dapat digambarkan sebagai berikut:

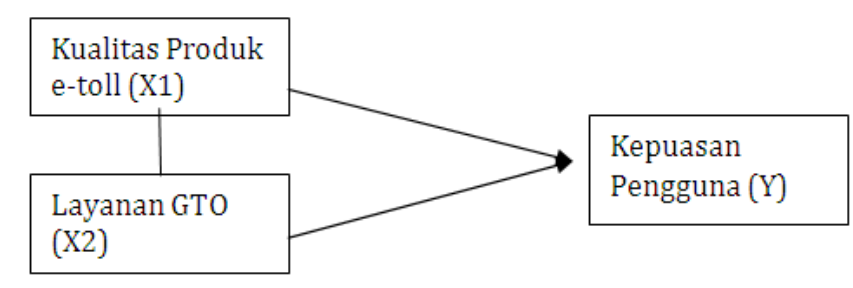

Gambar 1 Kerangka Berpikir

Berangkat dari kerangka berpikir tersebut, peneliti membuat spesifikasi dari indikator yang membentuk variabel-variabel tersebut. Operasionalisasi variabel yang digunakan pada penelitian ini adalah variabel independen, yaitu kompensasi kualitas produk $\left(\mathrm{X}_{1}\right)$ dan kualitas layanan $\left(\mathrm{X}_{2}\right)$; serta variabel dependen, yaitu kinerja kepuasan (Y) yang ditunjukkan pada tabel berikut. 
Tabel 1 Operasionalisasi Variabel

\begin{tabular}{|c|c|c|c|}
\hline Variabel & Indikator & Ukuran & Skala \\
\hline $\begin{array}{l}\text { Kualitas } \\
\text { Produk }\end{array}$ & $\begin{array}{ll}\text { - } & \text { Performance } \\
\text { - } & \text { Features } \\
\text { - } & \text { Conformance } \\
\text { - } & \text { Servicability } \\
\text { - } & \text { Durablity } \\
\text { - } & \text { Ashtetic } \\
\text { - } & \text { Perceived Ouality }\end{array}$ & Interval & $\begin{array}{l}\text { Skala } \\
\text { Likert }\end{array}$ \\
\hline $\begin{array}{l}\text { Kualitas } \\
\text { Layanan }\end{array}$ & $\begin{array}{ll}\text { - } & \text { Realibility } \\
\text { - Tangible } \\
\text { - Empathy } \\
\text { - Responsive } \\
\text { - } & \text { Assurance }\end{array}$ & Interval & $\begin{array}{l}\text { Skala } \\
\text { Likert }\end{array}$ \\
\hline $\begin{array}{l}\text { Kepuasan } \\
\text { pelanggan }\end{array}$ & $\begin{array}{ll}\text { - } & \text { Expectation } \\
\text { - } & \text { Performance } \\
\text { - } & \text { Comparison } \\
\text { - Confirmation/disconfirmation }\end{array}$ & Interval & $\begin{array}{l}\text { Skala } \\
\text { Likert }\end{array}$ \\
\hline
\end{tabular}

\section{HASIL DAN PEMBAHASAN}

\section{Profil Responden}

Profil responden bertujuan untuk mengetahui karakteristik 100 konsumen pengguna e-toll card. Profil responden ini dibutuhkan untuk mengetahui latar belakang responden. Berdasarkan hasil kuesioner, profil responden berdasarkan jenis kelamin (Gambar), didapatkan responden yang berjenis kelamin pria sebanyak 73 orang $(73 \%)$ dan sisanya sebanyak 27 orang $(27 \%)$ adalah wanita. Banyaknya pria lebih mendominasi diduga karena mayoritas pria lebih banyak menggunakan kendaraan roda empat daripada wanita.

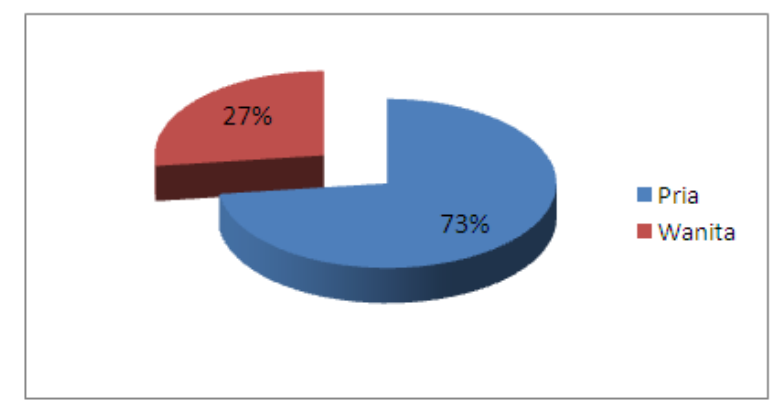

Gambar 2 Jenis Kelamin Responden

Berdasarkan usia responden (Gambar ) dapat dilihat bahwa kelompok usia responden $\leq 20$ tahun sebanyak 10 orang (10\%), untuk kelompok usia 21-30 tahun sebanyak 56 orang (56\%), kelompok usia responden 31-40 tahun sebanyak 16 orang (16\%), sementara untuk kelompok usia responden $>40$ tahun sebanyak 18 orang $(18 \%)$. 


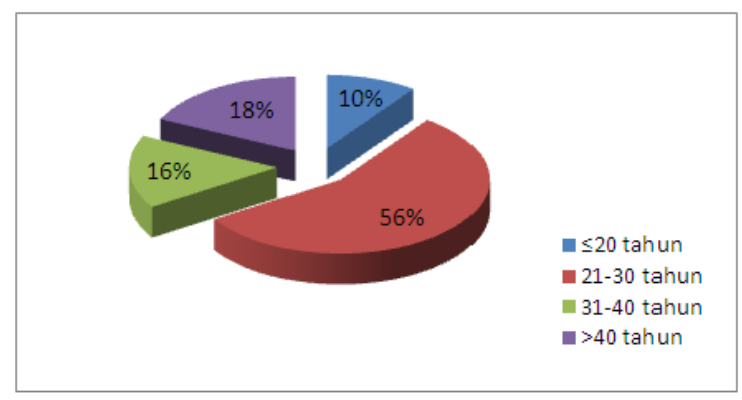

Gambar 3 Usia Responden

\section{Uji Indikator Variabel}

Nilai validitas dari seluruh indikator yang menjelaskan variabel kualitas produk e-toll card dinyatakan cukup valid. Artinya, responden cukup baik memahami pertanyaan dari kuesioner yang diajukan. Nilai realibilitas merupakan ukuran suatu kestabilan atau konsistensi responden dalam hal yang berkaitan dengan konstruksi pertanyaan yang merupakan dimensi sebuah variabel dan dibentuk dalam suatu bentuk kuesioner dinyatakan reliabel. Langkah selanjutnya adalah uji normalitas untuk mengetahui apakah beberapa sampel yang diambil berasal dari populasi yang sama (populasi data berdistribusi normal) dinyatakan normal. Sebaran data variabel dapat dikatakan baik karena sebaran titik - titik plot berada pada satu garis lurus (Sekaran, 2003).

Selanjutnya adalah uji heteroskedastisitas untuk mengetahui ada atau tidaknya penyimpangan, adanya ketidaksamaaan varian dari residual untuk semua pengamatan pada model regresi dan hasil uji bebas penyimpangan. Kemudian dilanjutkan ke uji multikolinearitas untuk melihat adanya hubungan linear antarvariabel independen dalam model regresi dan hasil uji bebas dari multikolinearitas. Terakhir adalah uji autokorelasi untuk untuk mengetahui ada atau tidaknya penyimpangan antara residual pada satu pengamatan dengan pengamatan lain pada model regresi dan hasil uji bebas autukorelasi.

\section{Hasil Pengujian Hipotesis}

$\mathrm{H}_{1}$ : Variabel Kualitas Produk dan Kualitas Layanan memiliki pengaruh yang signifikan secara simultan terhadap variabel Kepuasan Pelanggan

Dengan demikian diperoleh persamaan: Kepuasan Pelanggan $=0,441+0,580$ Kualitas Produk + 0,259 Kualitas Layanan. Pertama, Kualitas Produk $\left(\mathrm{X}_{1}\right)$ dan Kualitas Layanan $\left(\mathrm{X}_{2}\right)$ memiliki pengaruh yang signifikan secara simultan terhadap variabel Kepuasan Pelanggan. Kedua, besarnya pengaruh Variabel $\mathrm{X}_{1}$ dan kualitas layanan $\mathrm{X}_{2}$ secara simultan terhadap variabel $\mathrm{Y}$ dapat diketahui dengan melihat nilai Rsquare, yaitu $\mathrm{R}_{2}=0,676$. Artinya, $67,6 \%$ nilai dari variabel $\mathrm{Y}$ dipengaruhi variabel $\mathrm{X}_{1}$ dan $\mathrm{X}_{2}$, sedangkan sisanya sebesar 32,4\% dipengaruhi oleh variabel lain di luar penelitian. Selanjutnya nilai $\mathrm{R}$ (Koefisien Korelasi) diketahui sebesar 0,822. Hal ini berarti hubungan antara variabel terikat $\mathrm{Y}$ bersifat kuat (nilai $\mathrm{R} \geq 0,5$ ).

$\mathrm{H}_{2}$ : Variabel Kualitas Produk memiliki pengaruh yang signifikan secara individual terhadap variable Kepuasan Pelanggan

Persamaan yang diperoleh: Kepuasan Pelanggan $=0,513+0,811$ Kualitas Produk. Pertama, variabel Kualitas Produk (X1) berpengaruh secara signifikan terhadap variabel Kepuasan Pelanggan (Y). Kedua, hubungan bersifat kuat karena lebih dari 0,5. Ketiga, koefisien Determinasi $(\mathrm{R})^{2}=0,662$. 
Artinya, variabel Kualitas Produk memengaruhi Kepuasan Pelanggan sebesar 66,2\%; dan 33,8\% sisanya dipengaruhi variabel lain. Jika Kualitas Produk naik/meningkat, Kepuasan Pelanggan akan naik pula; dan sebaliknya. Jika Kualitas Produk turun, Kepuasan Pelanggan akan turun pula. Oleh karena itu dapat dilihat bahwa kualitas produk dapat diukur dari lima dimensi. Pertama, dimensi kualitas yang dirasakan dengan indikator berguna sesuai dengan kebutuhan pelanggan, praktis dalam proses pembayaran, dan mempersingkat waktu pembayaran. Kedua, dimensi ketahanan yang dirasakan dengan indikator kualitas akan produk kartu e-toll. Ketiga, dimensi keandalan (kemudahan bertransaksi). Keempat, dimensi kesesuaian (sesuai dengan kebutuhan). Kelima, dimensi kemampuan layanan (kemampuan staf memberikan pelayanan, kemampuan staf cepat untuk tanggap), asthetic (desain kartu e-toll) yang memengaruhi Kepuasan Pelanggan yang dapat diukur dari expectation (pelayanan yang diberikan sesuai harapan), performance (sensor GTO bekerja dengan baik), comparison (kinerja kartu e-toll sesuai dengan yang diharapkan), comparison (mengurangi kemacetan pada saat pembayaran tol).

$\mathrm{H}_{3}$ : Elastisitas atau kepekaan reaksi konsumen akan perubahan kualitas produk $e$-toll sangat peka (elastis) terhadap kepuasan pengguna kartu e-toll ini

$\mathrm{E}_{\mathrm{x}, \mathrm{y}} \rightarrow 0.811 \%$ perubahan kualitas produk $e$-toll $=\%$ perubahan kepuasan konsumen. Hal ini berarti setiap perubahan kualitas produk sebesar $10 \%$ berdampak 8,11\% (E > 1) pada kepuasan konsumen pengguna $e$-toll ini. Hal ini menunjukkan bahwa begitu besarnya fungsi yang dirasakan oleh pengguna e-toll dibandingkan cara konvensional biasanya. Hal ini penting bagi perusahaan penyedia produk ini untuk memerhatikan dimensi-dimensi yang menjadi kebutuhan konsumen yang telah terbukti signifikan di Hipotesis 2. Hal ini mengindikasikan bahwa pada diri konsumen sudah besar kesadaran akan pentingnya green technology walaupun konsumen tersebut tidak mendapatkan solusi kemacetan yang hingga kini masih terus berlangsung belum terbenahi. Konsumen kerap mendapatkan kendala dalam produk kartu e-toll. Akan tetapi, hal ini tidak mengurangi minat mereka untuk berperan serta dalam teknologi hijau ini. Sayangnya hal ini tidak didukung dengan data dan masih merupakan asumsi yang membutuhkan penelitian lebih lanjut.

$\mathrm{H}_{4}$ : Variabel Kualitas Layanan $\left(\mathrm{X}_{2}\right)$ memiliki pengaruh yang signifikan secara individual terhadap variabel Kepuasan Pelanggan (Y)

Persamaan yang diperoleh: Kepuasan Pelanggan $=0,605-0,775$ Layanan GTO. Artinya, pertama, variabel kualitas Layanan berpengaruh secara signifikan terhadap variabel Kepuasan Pelanggan. Kedua, koefisien korelasi $=0,775$; artinya hubungan bersifat kuat karena lebih dari 0,5. Ketiga, Koefisien Determinasi $\mathrm{R}^{2}=0,606$; artinya variabel Kualitas Layanan memengaruhi Kepuasan Pelanggan sebesar $60,6 \%$ dan 39,4\% sisanya dipengaruhi variabel lain. Jika Kualitas Layanan naik/ meningkat, Kepuasan Pelanggan akan naik pula; dan sebaliknya. Jika Kualitas Produk turun, Kepuasan Pelanggan akan turun pula. Oleh karena itu dapat dilihat bahwa Kualitas Layanan dapat diukur dari beberapa indikator, yaitu: berwujud (penampilan kartu $e$-toll, fasilitas GTO, sistem yang dterapkan), empati (sikap customer yang ramah), jaminan (proses pembayaran yang sesuai dengan prosedur yang diterapkan), daya tanggap (customer service cepat dalam menyelesaikan keluhan pelanggan) yang memengaruhi Kepuasan Pelanggan yang dapat diukur dari expectation (pelayanan yang diberikan sesuai harapan), performance (sensor GTO bekerja dengan baik), comparison (kinerja kartu e-toll sesuai dengan yang diharapkan), comparison (mengurangi kemacetan pada saat pembayaran tol).

$\mathrm{H}_{5}$ : Inelastisitas atau kepekaan reaksi konsumen akan perubahan kualitas (elastis) terhadap kepuasan pengguna e- toll ini

layanan GTO peka 
Simpulan: $\mathrm{E}_{\mathrm{x}, \mathrm{y}} \rightarrow 0.775 \%$ perubahan kualitas produk $e$-toll $=\%$ perubahan kepuasan konsumen. Hal ini berarti setiap perubahan kualitas produk sebesar $10 \%$ berdampak hanya $7.75 \%$ (E $>1 \%$ ) pada kepuasan konsumen pengguna $e$-toll ini. Hal ini menunjukkan bahwa besar fungsi yang dirasakan oleh pengguna e-toll dibandingkan cara konvensional biasanya. Hal ini penting bagi perusahaan penyedia layanan GTO untuk memerhatikan dimensi yang menjadi kebutuhan konsumen yang telah terbukti signifikan pada Hipotesis 4. Hal ini mengindikasikan bahwa pada diri konsumen sudah besar kesadaran akan pentingnya green technology walaupun konsumen tersebut tidak mendapatkan solusi kemacetan yang hingga kini masih terus berlangsung belum terbenahi. Konsumen ini pun kerap mendapatkan kendala di layanana GTO namun ternyata tidak mengurangi minat mereka untuk berperan serta dalam teknologi hijau ini, sayangnya pendapat ini tidak didukung dengan data masih merupakan asumsi yang membutuhkan penelitian lebih lanjut.

\section{SIMPULAN}

Hasil yang didapat dari pengolahan data adalah sebagai berikut. Pertama, variabel kualitas produk e-toll card dan layanan GTO berpengaruh secara signifikan terhadap kepuasan konsumen. Sehingga hal ini menjadikan perlunya penyedia memerhatikan dimensi yang dibutuhkan konsumen agar kepuasan konsumen terpenuhi. Kedua, elastisitas e-toll card dan layanan GTO tinggi sekali atau peka sekali. Kepuasan konsumen dirasakan jika terjadi perubahan kenaikan ataupun penurunan kualitas produk dan layananan. Sehingga pihak penyedia kartu dan pelayanan di pintu GTO perlu untuk memerhatikan hal yang berkaitan dengan ini.

\section{Saran}

Indikasi konsumen untuk sadar tentang pentingnya green technology dirasakan cukup besar walaupun mereka tidak mendapatkan solusi kemacetan yang hingga kini masih terus berlangsung dan belum terbenahi. Konsumen pun kerap mendapatkan kendala di layanana GTO namun hal tersebut ternyata tidak mengurangi minat mereka untuk berperan serta dalam teknologi hijau ini. Sayangnya, pendapat ini tidak didukung dengan data; masih merupakan asumsi yang membutuhkan penelitian lebih lanjut. Karena itu, sebaiknya hal yang memengaruhi perilaku konsumen berdasarkan elastisitas konsumen dilihat dari sudut ekonomi dan nonekonomi diteliti lebih dalam. Dengan begitu, prediksi akurat tentang seberapa besar peran ekonomi ke depan dan keselarasan teknologi hijau secara ekonomi yang lebih efisien bisa diperoleh.

\section{DAFTAR PUSTAKA}

Arendt, S., \& Brettel, M. (2010). Understanding the influence of corporate social responsibilit on corporate identity, image, and firm performance. Management Decision, 48(10), 1469-1492.

Arief. (2007). Pemasaran Jasa dan Kualitas Pelayanan - Bagaimana Mengelola Kualitas Pelayanan agar Memuaskan Pelanggan (Edisi Pertama). Malang: Bayu Media Publishing.

Bank Mandiri. (n.d.). E-toll Card. http://www.bankmandiri.co.id/article/mandiri-etoll- card.asp

GoldBank. (2012, 16 April). Layanan e-toll Pass Makin Mudah. Diakses dari http://www.goldbank.co.id/channel/moneter/sub-moneter-3/layanan_etoll_pass_makin_mudah.html 
Kotler, P., \& Armstrong, G. (2006). Principles of Marketing (1 $1^{\text {th }}$ Edition). New Jersey: Pearson Prentice Hall.

Novikova, K. (2009). A study of customer satisfaction factors and employee satisfaction in the hospitality industry. Southern Illinois University at Carbondale. http://search.proquest.com/docview/305000386

Sekaran, U. (2003). Research Methods for Business, a Skill Building Approach (4th Edition). New York: John Wiley \& Sons.

Vachon, S., \& Klassen, R. (2006). Extending green practices across the supply chain: the impact of upstream and downstream integration. International Journal of Operations \& Production Management, 26(7), 795-821 